\title{
RESEARCH OF FACTORS OF NON PERFORMING AGRICULTURAL LOANS BY PRIMARY DATA PANELS
}

\author{
Almir Muhović ${ }^{1}$, Nikola Radivojević ${ }^{2}$, Nikola Ćurčićc ${ }^{3}$ \\ *Corresponding author E-mail: radivojevic034@gmail.com
}

A R T I C L E I N F O
Review Article
Received: 18 May 2019
Accepted: 03 June 2019
doi:10.5937/ekoPolj1902569M
UDC 336.77/.78:338.43

Keywords:

Agricultural Loans, non-

Performing Loans, profitability,

A B S T R A C T

The paper examines factors that influence the occurrence and movement of nonperforming agricultural loans in Serbia, Montenegro and Bosnia and Herzegovina.

The aim of the paper is to determine the direction and significance of the relationship between the key micro and macroeconomic factors and the impractical agricultural loans in these countries, but also to point out the importance of applying dynamic data panel evaluators when it comes to the study of this problem.

capital adequacy ratio, , return

(C) 2019 EA. All rights reserved. on own funds, returned on total assets.

JEL: G24, C22, C52, C53

\section{Introduction}

The paper examines the factors of the occurrence of nonperforming agricultural loans, on the example of the data panel of the three countries: Serbia, Montenegro and Bosnia and Herzegovina. Research related to this problem in the mentioned markets is very rare and, according to the author's knowledge, is mainly related to the study of different determinants of the appearance of total nonperforming loans, without separation into individual categories. For example, research conducted by Stakic (2014) refers to the study of six micro and macro variables that affect the occurrence of nonperforming loans in the banking system of Serbia. He studied the impact of four

1 Almir Muhović, Ph.D, Assistant Professor, University Business Academy, Faculty of Applied Management, Economics and Finance, Jevrejska No. 24, 11000, Belgrade, Serbia,Phone: +381631070932, e-mail:amuhovic@gmail.com, ORCID ID https://orcid. org/0000-0003-1479-2654

2 Nikola Radivojević, Ph.D, Professor, Technical College of Applied Studies, Str. Kosovska, No. 8, 34000, Kragujevac, Serbia, Phone:+381600555173, e-mail: radivojevic034@gmail.com, ORCID ID 0000-0002-6137-4431

3 Nikola Ćurčić, PhD, Assistant Professor, University Union Nikola Tesla, Faculty of Management, Sremski Karlovci, Njegoseva 1, Sremski Karlovci, Serbia, Phone: +381 64 2777771, e-mail: nikolavcurcic@yahoo.com, ORCID ID https://orcid.org/0000-0003-3375-2690

http://ea.bg.ac.rs 
micro variables such as profitability, capital adequacy ratio, provision for covering over potential losses, ownership structure of banks and the impact of two brand variables such as concentration of banks and growth of gross domestic product. Characteristic of this research is that the method used for the simplest least squares is used to evaluate the data panel. The application of this method requires the fulfillment of very strict conditions and assumptions of the model, which when dealing with panel data can always be called into question. Radivojević and Jovović (2017) studied the influence of three macro and three micro factors on the occurrence and movement of nonperforming loans using the data panel. The panel consisted of 15 developing countries, including Serbia, Montenegro and Bosnia and Herzegovina. The significance of this research is that they have used a number of different static and dynamic techniques for evaluating the data panel, ranging from the simplest least-squares method to the mid-stage differentiated general method of moments. A contraction of high-quality demand for loans and the expansion of nonperforming loans, which started to burden bank balance sheets and their results, led to a significant tightening in banks' standards and conditions for new lending (Durkalić \& Ćurčić, 2019) and most countries compete that with investments from abroad (Huxley \& Sidaoui, 2018). Todorović et al. (2018) declared that available information on performance indicators and nonperforming loans needs to be reliable, comparable, and clear. Muhović et.al (2018), conducted the only known research on the study of factors of the occurrence of impractical agricultural loans on the example of the data panels of Serbia, Montenegro and Bosnia and Herzegovina. His study was concentrated on the impact of three key macro factors of non-performing agricultural loans, unemployment rates, growth rates of gross domestic product and inflation rates, and three key micro variables such as return on own funds and total assets and an indicator of the capital adequacy of the bank. The results of their research indicate that there is a negative and statistically significant link between unemployment and non-performing loans, that there is no statistically significant relationship between the growth rate of gross domestic product and these loans, and that there is a positive and significant relationship between the inflation rate and the occurrence of these nonperforming loans. Also, the authors conclude that there is either negative or positive statistically significant relationship between the return on the active, i.e. the indicators of capital adequacy and the occurrence of non-performing loans. However, the conclusions of this research are based on the application of static data panel estimates, which cannot detect the effects of legendary variables. The estimates of model parameters were obtained using the smallest squares method and the fixed effect method. Bearing in mind the limitations of the application of the smallest squares to the panel data, as well as the limitations of the fixed effects method (for more details see this in Radivojević et.al 2019), the results of this study should be taken with caution. Hence, the aim of this paper is to use the dynamic data model of the dataset using the dynamic model of the certificate or deny the findings of the aforementioned research, that is, to indicate the importance of applying the techniques for evaluating the dynamic data model of the data panel. 


\section{Materials and methods}

The survey was conducted on a sample of data panels of Serbia, Montenegro and Bosnia and Herzegovina for the period from 2000 to 2015. The data was collected from the official World Bank website and the Bank for International Settlements. The dynamic data panel model is shown as follows:

$N P L i, t=$

$\beta_{1}+\beta_{2}$ npls $_{i, t-1}+\beta_{3} g d p_{i, t}+\beta_{4} u_{n r} r_{i, t}+\beta_{5}$ inf $_{i, t}+\beta_{6}$ roa $_{i, t}+\beta_{7}$ roe $_{i, t}+\beta_{8}$ car +

$+\varepsilon_{i, t}$

Where there are:

\begin{tabular}{|r|l|}
\hline$N L P_{i, t}$ & - NPL rate for $\mathrm{i}$ - country in $(\mathrm{t})$ time period \\
\hline$N L P_{i, t-1}$ & - NPL rate for i- country in $(\mathrm{t}-1)$ time period \\
\hline$g d p_{i, t}$ & - The rate of gross domestic product for i- country in $(\mathrm{t})$ time period \\
\hline$u n r_{i, t}$ & - Unemployment rate for i- country in $(\mathrm{t})$ time period \\
\hline$i n f_{i, t}$ & - Inflation rate for i- country in $(\mathrm{t})$ time period \\
\hline$r o e_{i, t}$ & - rate the return on equity for i- country in $(\mathrm{t})$ time period \\
\hline $\operatorname{roa}_{i, t}$ & - rate of return on assets for i-country in $(\mathrm{t})$ time period \\
\hline $\operatorname{cap}_{i, t}$ & - Capital adequacy ratio between equity and assets for i- country in $(\mathrm{t})$ time \\
\hline
\end{tabular}

The model thus described allows for the influence of NPL from the previous period on a dependent variable, with the NPL variable being dependent on the current period. Independent variables are the unemployment rate, gross domestic product growth rate, inflation rate and rate of return on own funds and assets and capital adequacy ratio. To evaluate the models the following methods are used.

The dynamic model was estimated using the one-step differentiated generalized momentum method (GMM), developed by Arellano and Bond (1991). The selection of this evaluator is in line with the empirical research of Louziset et.al (2010) and De Bocka and Demianets (2012). Their assessment began with the transformation of all variables by differentiation, and then using the difference of GMM. GMM estimation is based on the transformation of the first order of the equation (2.2.1) in the following way:

$$
\begin{aligned}
& \Delta N P L i, t=\beta_{1}+\beta_{2} \Delta n p l s_{i, t-1}+\beta_{3} \Delta g d p_{i, t}+\beta_{4} \Delta u n r_{i, t}+\beta_{5} \Delta i n f_{i, t}+ \\
& \beta_{6} \Delta \text { ennr }_{i, t}+\beta_{7} \Delta \text { hip }_{i, t}+\beta_{8} \Delta \text { roa }_{i, t}+\beta_{9} \Delta \text { roe }_{i, t}+\beta_{10} \Delta \text { car }+\beta_{11} \Delta l l p_{i, t}+ \\
& \beta_{12} \Delta n i m r_{i, t}+\beta_{13} \Delta n i m r_{i, t-1}+\beta_{14} \Delta n i m r_{i, t-2}+\varepsilon_{i, t}
\end{aligned}
$$

where $\Delta$ is the operator of the first differentiation.

Since it is expected in equation (2.2.2) that the dependent variable with the position (dependent variable from the previous period) $\Delta n p l s_{i, t-1}$ be correlated with $\Delta \varepsilon_{i, t}$ , implies bias in evaluation. Moreover, this model can cause bias because of the endogenous explanatory variables, which leads to autocorrelation problems. Arellano and Bond (1991) state that the problem of autocorrelation between the dependent 
variable of the previous period and the faults (residuals) of the model can be solved by adding additional instruments to the model of dynamic panel data. The point is that in the models (2.2.2), instruments that are not correlated with the model error shall be found. Valid instrument is $n p l s_{i, t-2}$, because it is largely correlated with $n p l s_{i, t-1}-n p l s_{i, t-2}$, and is not correlated with $\varepsilon_{i, t}-\varepsilon_{i, t-1}$. The basic idea behind the GMM assessment is that we have valid instruments that can be tested with the Sargan test.

In addition to the GMM method, the two-level method of the smallest squares is also used to estimate the model, which is also used to solve the endogenous problem of one or more explanatory variables. More precisely, this method was used under the assumption that the dependent variable from the previous period was instrumentalized with all the regressors from the previous period in the model. In addition to these two assessors, the model was also evaluated using the dynamic model of a fixed effect, since it is assumed that the selected countries have their specificities that are time-invariant.

\section{Results}

The first step in working with panel data involves descriptive analysis of collected data and stationary analysis. Table 1 shows the results of descriptive analysis.

Table 1. Descriptive statistics panel of data (\%)

\begin{tabular}{|c|c|c|c|c|c|}
\hline Variables & Volume & Middle & St.dev. & Minimum & Maximum \\
\hline NPL & 48 & 12,751 & 6,783 & 2,900 & 24,100 \\
\hline GDP & 48 & 4,745 & 4,195 & $-3,120$ & 17,290 \\
\hline UNR & 48 & 20,467 & 4,760 & 7,250 & 31,100 \\
\hline INF & 48 & 10,407 & 19,944 & $-0,910$ & 95,010 \\
\hline ROA & 48 & 0,285 & 1,397 & $-4,790$ & 4,000 \\
\hline ROE & 48 & 1,902 & 8,708 & $-25,670$ & 19,170 \\
\hline CAP & 48 & 21,336 & 7,133 & 6,000 & 42,000 \\
\hline
\end{tabular}

Source: Authors

As you can see the level of NPL ranges from $2.9 \%$ to $24.10 \%$. The average NPL value is approximately $12.75 \%$, which highlights the need to pay more attention to credit policy in these countries in the future. GDP shows both negative and positive values, indicating high fluctuation and stagnation in economic growth in these countries, with the notion that the average growth rate in the observed period is positive, indicating that these countries achieved economic growth. The analysis of the unemployment rate indicates that these countries face all the major unemployment problems, as well as a high average inflation rate. The high values of the standard deviation of macroeconomic variables can be interpreted as a consequence of large oscillations in economy and economic activities in these countries. The values of microeconomic variables are relatively similar among countries and indicate that despite the fact that the minimum value of profitability 
indicators was about $4.8 \%$, banks profitably operate in these countries. The relatively high value of capital adequacy indicators implies the resilience of the banking sector to extreme shocks and macroeconomic instability. On the other hand, the relatively high value of the standard deviation of this parameter can be an indication of changes in prudential requirements during the observed period (Muhović et.al (2018). An analysis of the stationary data panel was performed using the Levin-Lin-Chu unit root test. The results given in Table 2 reveal that the variables NPL, GDP and CAP are non-stationary. While other variables are stationary, (Muhović et.al (2018). The unstableness of the GDP is justified by the great economic instability in these countries, while the lack of stability in the indicators of capital adequacy explains the frequent changes in prudential requirements, as a consequence of frequent reforms in the financial sector. After the firstorder differentiation, non-stationary series became stationary.

Table 2. Results of the LLC test

\begin{tabular}{|c|c|c|c|}
\hline \multicolumn{2}{|c|}{ Variable } & test value & $p$-value \\
\hline \multirow{2}{*}{$N P L$} & Level & 6,37925 & 0,3821 \\
\hline & 1. difference & 25,8609 & 0,0002 \\
\hline \multirow{2}{*}{ UNR } & Level & 20,4845 & {$[0,0023]$} \\
\hline & 1. difference & & \\
\hline \multirow{2}{*}{$G D P$} & Level & 11,1123 & 0,0850 \\
\hline & 1. difference & 42,0469 & 0,0000 \\
\hline \multirow{2}{*}{ INF } & Level & 50,4943 & 0,0000 \\
\hline & 1. difference & & \\
\hline \multirow{2}{*}{ ROE } & Level & 14,2472 & 0,0270 \\
\hline & 1. difference & & \\
\hline \multirow{2}{*}{$R O A$} & Level & 22,6279 & 0,0009 \\
\hline & 1. difference & & \\
\hline \multirow{2}{*}{$C A P$} & Level & 11,0279 & 0,0875 \\
\hline & 1- difference & 21,595 & 0,0014 \\
\hline
\end{tabular}

Note: the test is performed for a confidence level of $5 \%$ of the test value Source: Authors

The second step in working with panel data was to examine the correlation between the selected variables. High correlation between independent variables may also be implicated by the presence of multicolority, which generates certain problems in econometric analysis. A correlation of over 0.8 is considered high and may generate certain problems in the research. Correlations between variables are shown in Table 3. As one can expect high correlations, there are two variables concerning the profitability of banks, i.e. between ROA and ROE (0.959). In order to avoid potential problems of the ROE variant, the ROE variant has been excluded from further research. 
Table 3. Correlation matrix

\begin{tabular}{|l|c|c|c|c|c|c|l|}
\hline NPL & GDP & UNR & INF & ROE & ROA & CAP & \\
\hline 1,000 & $-0,101$ & $-0,188$ & 0,247 & $-0,402$ & $-0,393$ & 0,271 & NPL \\
\hline & 1,000 & $-0,331$ & 0,086 & $-0,369$ & $-0,332$ & $-0,027$ & GPD \\
\hline & & 1,000 & $-0,497$ & 0,209 & 0,186 & $-0,473$ & UNR \\
\hline & & & 1,000 & $-0,115$ & $-0,154$ & 0,732 & INF \\
\hline & & & & 1,000 & 0,959 & 0,038 & ROE \\
\hline & & & & & 1,000 & $-0,020$ & ROA \\
\hline & & & & & & 1,000 & CAP \\
\hline
\end{tabular}

Source: Authors

In Table 4, the results of the dynamic model estimation are presented using the three previously described assessors.

Table 4. Results of the assessment of the dynamic model parameters for all three countries for the period from 2000 to 2015 (dNPL - dependent variable)

\begin{tabular}{|c|c|c|c|c|c|c|c|c|c|}
\hline \multirow{3}{*}{$\begin{array}{l}\text { Variable } \\
\text { Constant }\end{array}$} & \multicolumn{3}{|c|}{\begin{tabular}{|c|} 
Evaluator \\
Dynamic fixed effect \\
\end{tabular}} & \multicolumn{3}{|c|}{ 2SLS regression } & \multicolumn{3}{|c|}{ One-degree GMM ratings } \\
\hline & \multirow{2}{*}{\begin{tabular}{|c|} 
Coefficient \\
18,116
\end{tabular}} & \multicolumn{2}{|c|}{ p verbal } & \multirow{2}{*}{\begin{tabular}{|l|} 
Coefficient \\
5,462
\end{tabular}} & \multicolumn{2}{|c|}{ p verbal } & \multirow{2}{*}{$\begin{array}{c}\text { Coefficient } \\
7,615\end{array}$} & \multicolumn{2}{|c|}{ p verbal } \\
\hline & & 0,000 & $* * *$ & & 0,008 & $* * *$ & & 0,340 & \\
\hline NLPt-1 & $-0,296$ & 0,161 & & $-0,396$ & 0,000 & $* * *$ & $-0,523$ & 0,000 & $* * *$ \\
\hline$d G P D$ & $-0,156$ & 0,220 & & $-0,182$ & 0,000 & $* * *$ & $-0,417$ & 0,003 & $* * *$ \\
\hline$U N P$ & $-0,819$ & 0,000 & $* * *$ & $-0,179$ & 0,008 & $* * *$ & $-0,171$ & 0,440 & \\
\hline$I N F$ & 0,126 & 0,483 & & $-0,134$ & 0,008 & $* * *$ & $-0,605$ & 0,011 & $* *$ \\
\hline $\mathrm{ROA}$ & $-2,013$ & 0,000 & $* * *$ & $-1,661$ & 0,205 & & $-0,289$ & 0,683 & \\
\hline$d C A R$ & 0,534 & 0,024 & $* *$ & $-0,002$ & 0,994 & & $-0,788$ & 0,003 & $* * *$ \\
\hline \multirow{3}{*}{$R 2$} & \multirow{3}{*}{\multicolumn{3}{|c|}{0,258}} & \multirow{3}{*}{\multicolumn{3}{|c|}{0,185}} & $\operatorname{AR}(1)$ & \multicolumn{2}{|c|}{$\begin{array}{l}-1,711 \\
(0,087)\end{array}$} \\
\hline & & & & & & & $\operatorname{AR}(2)$ & \multicolumn{2}{|c|}{$\begin{array}{c}1,576 \\
(0,115)\end{array}$} \\
\hline & & & & & & & Sargan test & \multicolumn{2}{|c|}{$\begin{array}{l}35,049 \\
(0,371)\end{array}$} \\
\hline
\end{tabular}

Source: Authors

Note: Assessments using 2SLS evaluators have robust (HAC) errors. The brackets are given $\mathrm{p}$ - values. The H-matrix was used to evaluate the variance-covariance matrix.

\section{Discussions}

The results shown in Table 4 indicate that the applied assessors can reliably be used to examine the impact of determinants of nonperforming agro-credits in countries that are the subject of research in this paper. However, the determination coefficient values 
(R2) are quite low. In the case of a dynamic fixed effect assessor, it is 0.28 , while in the case of a two-stage method of the smallest squared it is 0.185 . They indicate that only $28 \%$ and $18.5 \%$ of the variability in the dependent variable can be explained by the selected variables in the model. In the case of a third grader, the Sargan test shows that all instruments included in the model are valid. Also, the results of autocorrelation tests show the presence of autocorrelation of the first, or the absence of the second order, which is in accordance with the conditions for applying this assessor. The analysis of the obtained data reveals that there is a clear link between the levels of nonperforming loans from the previous period and the current rate of non-performing agricultural loans. This can be interpreted as having the credit conditions unchanged, as well as habits, i.e. credit rating of the debtor. An interesting result in relation to research carried out using static data panel evaluators (Muhović et.al, (2018) is that there are statistically significant and negative correlations between gross domestic product growth rates and the rate of non-performing agricultural loans. This finding is consistent with the expectations and findings of numerous authors, such as Makri et.al (2014) and Jovović (2014). Namely, it is expected that impaired loans are closely linked to the economic and business cycle, i.e. behind every financial crisis there are macroeconomic factors, such as a decline in aggregate economic activity. Financial crisis pinpointed on weaknesses that were more than obvious on derivatives market. (Dudić et al., 2018). When growth slows down or becomes negative, borrowers reduce cash inflows, which make it difficult for them to pay interest and principal on bank loans. In such circumstances, borrowers will face a lack of liquidity and delays in meeting their financial obligations towards banks will likely increase (Radivojević and Jovović, 2017). Since these countries have a large share of agriculture in the total gross domestic product, this is expected to be a high value of this coefficient. In this analysis, it is about 0.42 , which implies that with each decrease in the economic activity of these countries from $0.42 \%$ leads to the growth of nonperforming loans of $1 \%$. The results of the first two evaluators indicate that there is a significant but negative correlation between the unemployment rate and the non-performing agricultural loans, while the third assessor does not have a statistically significant link. This finding is in contrast to numerous findings, Nkusu (2011), Louzis et.al (2012), Makri et.al (2014) and the view that unemployment reduces available household income and weakens the borrower's ability to pay its loan installments on time. This finding can be justified by the fact that people who are left unemployed do not take loans or that the bank does not approve such loans to such people. The reason is also found in the fact that in these countries there are mechanisms for securing loans in the event of a debtor without a job. The reasoning behind is, however, the fact that the unemployment rate of this sector in the overall unemployment rate in these countries is relatively small, and that the fluctuations in the overall rate do not affect the creditworthiness of agricultural producers, but also the fact that a large number of the labor force engaged seasonal jobs in this sector are not recorded in labor markets. The results of the research using the static model are contradictory. By using a pooled OLS method, a positive relationship was established; while a negative relationship was established using the FE model. 
Inflation is an important factor that affects the creditworthiness of the borrower. In the study of Muhovic et.al (2018), using the pooled OLS method that is inexistent, i.e. using FE model to have a positive relationship, while the results of the application of dynamic assessors indicate a negative relationship, which explains that inflation increases the prices of agricultural products and the earnings of agricultural producers grow faster than the inflation rate, which is in contrast to Mileris (2012) and Nkusus (2011). While this finding should be taken with caution, bearing in mind that negative inflation rates have been recorded in Montenegro and Bosnia and Herzegovina, so that these data can influence the panel analysis result. Regarding the relationship between ROA and NPL, a statistically significant link was not revealed, which can be explained that the quality of bank management has no impact on the occurrence of non-performing agricultural loans. Also, it is interesting merger and acquisition (Agarwal et al., 2018). The results of the static model application indicate that there is a positive link between the capital adequacy indicators and the NPL, while the results of the research in this paper obtained using the dynamic FE model confirm the findings of the previous study. However, the application of the GMM model indicates the existence of a negative link, which is justified by the fact that banks with higher rates are entering risky activities ((Rime, 2001, Luise et al. (2012), Garsiy and Fernandez (2007)).

\section{Conclusions}

In this paper, literature on the most significant micro and macro factors that influence the occurrence of nonperforming loans was considered. More precisely, the work focuses on the impact of the movement of gross domestic product, inflation and unemployment rates, on the one hand, and indicators of profitability and performance of banks, as well as the level of adequacy of bank capital coverage, on the other hand, on the occurrence and movement of nonperforming agricultural loans, with the note that in this work under agricultural loans are meant long-term investment loans approved for the purchase of agricultural machinery, construction or adaptation of facilities for intentions of agricultural production and infrastructure works, establishment or extension of livestock farms etc. The research was carried out using the data panel of Serbia, Montenegro and Bosnia and Herzegovina. Data were collected for the period from 2000 to 2015 .

In addition to examining the significance of the aforementioned micro and macroeconomic factors on the occurrence and movement of these impractical loans in these countries, the aim of the work is to point out the importance of using dynamic data panel evaluators, and to point out the differences in the findings obtained by applying these evaluators data panel in relation to the use of static data panel evaluators, which were used in a similar study.

The results that have come to light in this paper can be summarized as follows: 1) that there is a statistically positive link between the levels of nonperforming loans from the previous and the current period, which explains that the conditions for granting loans and the target group between these two periods have not changed, as well as 
the habits of the borrowers; 2) that there is a statistically significant and negative correlation between gross domestic product growth rate and dependent variable, which is contrary to the findings of Muhović et.al (2018), who did not reveal the existence of a statistically significant link between these variables; 3 ) that based on GMM assessors, it can be concluded that there is no statistically significant link between unemployment and non-farming agricultural loans, while the other two point to the existence of a negative link. The results of the abstracted studies are also contradictory, and no clear conclusion can be drawn from them on the nature of the relationship between these two variables; 4) that inflation has a negative impact on the occurrence and movement of non-performing loans. Based on the results presented by Muhović et.al (2018), a clear view on this relationship cannot be drawn because the obtained conjunction findings are obtained using two different assessors of the static model of the data panel; 5) that there is no statistically significant link between ROA and NPL; 6) that there is a rate of capital adequacy of the bank in a negative relationship with the dependent variable.

Bearing in mind the results of the research, but also the findings of the study, which is referred to in this paper with which the results are comparable, one can conclude on the necessity of 1) the application of dynamic data panel models, since they provide a deeper insight into the presence of the effects of residual NPLs at the current NPL and 2) the need to use different assessors, and the comparison of their results.

\section{Conflict of interests}

The authors declare no conflict of interest

\section{References}

1. Agarwal, N., Kwan, P., \& Paul, D. (2018). Merger and acquisition pricing using agent based modelling. Economics, Management \& Financial Markets, 13(1), 84-99.

2. Boudriga, A., Taktak, N., Jellouli, S. (2009), Bank Specific, Business and Institutional Environment Determinants of Nonperforming Loans: Evidence from MENA Countries. Paper presented at Economic Research Forum $16^{\text {th }}$ Annual Conference Cairo.

3. Dudić., B., Drahošová., M., Lukić., J., Dudić., Z., Smoleň., J., Mirković., V. (2018), Counterparty Credit Risk Closure: Challenges in Big Data Era, Proceedings of the 31st International Business Information Management Association Conference, IBIMA 2018: Innovation Management and Education Excellence through Vision 2020.

4. Durkalić, D., Ćurčić, M., (2019), Mutual influence of the international investment position and the net government position with the banking sector of the Republic of Serbia, Ekonomika, Niš, 65 (1), 78-91.

5. Godlewski, J. C. (2005), Bank capital and credit risk taking in emerging market economies. Journal of Banking Regulation, 6(2), 128-145.

6. Garsiya, M. T., and Fernandez, R.M.D. (2007), Risk-taking behavior and ownership in the banking industry: The Spanish evidence. Journal of Economics and Business, $60(4), 332-354$. 
7. Huxley, S. J., \& Sidaoui, M. (2018). Gaining market share in emerging markets portfolios by moderating extreme returns: The case of Peru. Economics, Management \& Financial Markets, 13(3), 37-55.

8. Jovovic, J. (2014), Determinants of Non-Performing Loans: Econometric Evidence Based on 25 Countries. Master thesis, City University London.

9. Louzis, P. D., Vouldis, A. T., Metaxas, V. L. (2012), Macroeconomic and bankspecific determinants of non-performing loans in Greece: A comparative study of mortgage, business and consumer loan portfolios. Journal of Banking and Finance, 36 (1), 1012-1027.

10. Makri, V., Tsagkanos, A., Bellas, A. (2014), Determinants of Non-Performing Loans: The Case of Eurozone. Panoeconomicus, 2, 193-206.

11. Makri, V., Papadatos, K. (2012), How accounting information and macroeconomic environment determine credit risk, Evidence from Greece. International Journal of Economic Sciences and Applied Research, Vol. 7 (1), 129-143.

12. Mileris, R. (2012), Macroeconomic Determinants of Loan Portfolio Credit Risk in Banks. Izerine Ekonomika-Engineering Economics, 23(5), 496-504.

13. Muhović, A. Radivojevic, N, Curcic, N. (2018), Empirical research determinant of NPL in emerging markets by using the fixed effects method: Study of the case of Serbia, Montenegro and Bosnia and Herzegovina, Vojno delo, No. 7.,335 - 344.

14. Nkusu, M.(2011), Nonperforming Loans and Macrofinancial ulnerabilities in Advanced Economies. IMF Working Paper 161.

15. Radivojevic, N., Cvijanovic, D., Sekulic D., Pavlovic, D., Maksimovic, G., Jovic, G. (2019), Econometric model of non-performing loans determinants, Physica A: Statistical Mechanics and its Applications, Vol. 520, 481-488.

16. Radivojevic, N., Jovovic, J., (2017), Examining of determinants of non-performing loans, Prague economic paper, 26 (3), 300-316.

17. Stakić, N., (2014), Determinants of trends in the level of non-performing loans in the banking sector in Serbia. Bankarstvo, No. 4.,122 -146.

18. Tabak, B. Guerra, M. S., Solange, M, Lima, E.JA., Chang, E.J. (2005), The StabilityConcentration Relationship in the Brazilian Banking System. The Banco Central do Brazil Working Papers, 145.

19. Todorović, V., Furtula, S., Durkalić, D., (2018), Measuring performance of the Serbian Banking sector using CAMELS model, TEME, Niš, 42(3), 961-977, DOI: 10.22190/TEME1803961T.

20. Vučinić, M. (2014), Financial Stability - Comparative Analysis: Montenegro, Serbia and the Netherlands, Journal of Central Banking Theory and Practice, No. 1, 63-93.

21. Wooldridge, J., M. (2009), Introductory econometrics: a modern approach. 4th ed. Mason, Ohio: South-Western Cengage Learning. 